\title{
Review and Selection on Human Hypothesis in Higher education Management
}

\author{
Ninghe Geng ${ }^{1, a}$, Junming Niu ${ }^{2, b}$ and Qi Tang ${ }^{3, c}$ \\ ${ }^{1}$ No. 23 East Software Center Road, Software Center Buliding No.15, Shahekou District, Dalian, \\ Liaoning Province, China. \\ ${ }^{2}$ Dalian University of Technology, Faculty of Hunmanities and Social Sciences, Graduate school of \\ Education, Gaoxing District, Dalian, Liaoning Province, China. \\ ${ }^{2}$ Hainan University, No.58 of Renmin Avenue, Meilan District, Haikou, Hainan Province, China \\ a46900815@qq.com, b814397875@qq.com, c1016510085@qq.com
}

Keywords: Higher education management; Human hypothesis; Review; Selection

\begin{abstract}
The human nature serves as the foundation and the direction of higher education management research, and always correlates to higher education management. And its reasonable interpretion is the logistic precondition of the theoretic system construction of overall higher education management. Various human hypothesis will lead to various thoughts, methods and path of higher education management. Against this major background that building first-class university and higher powerful education nation, to review on human character in higher education management has referential and pioneering value for colleges and universities in the re acquaintance of higher education management, the exploration of its regular and the promotion of the efficiency and level of higher education systematic management.
\end{abstract}

\section{Introduction}

Higher education management differs from general management serving for human. Therefore, "what kind of human to be trained" and "how to train human" have always been the fundamental problems in higher education management. Against this major background that building first-class university and higher powerful education nation, it seems unrealistic and impossible for all colleges and universities to step into first-class universities. However, they all shoulder the important task that bring up the builders and successors of the Chinese characteristic socialism, which requires them to review on the human hypothesis of higher education management, and to integrate humanistic ideas such as "moral education", "the cultivation and implementation of socialist core values" into the process of higher education management.

\section{The hypothesis of human nature is the beginning for higher education management}

Higher education Management should serve for human nature moulding. The ultimate meaning of people to have correctly understanding of human nature and provide higher education management as it requires lies in human cultivation, human education and human promotion." Henry Sisk thinks, "Each administration behavior is on the basis of the nature of its work and the implicit assumption of human nature". He is a professor of business administration at Texas State University. ${ }^{2}$ Higher education management, as a special type of administration behavior, also involves in human nature. "The hypothesis of human nature is the humanistic foundation and logistic presupposition of the construction of overall education management theory system.”3

From the perspective of human nature theory, higher education management can be regarded as a kind of micro higher education management mode, which is a full set of theory and practice mode relating to the idea, mode and path of higher education management that bases on various human nature theories. Various human nature theories will lead to different higher education management thoughts. And a higher education management pattern often directly or indirectly roots in one or 
more hypothesis of human nature. To review the human nature of higher education management and rethink its human nature theory contribute to a better understanding of higher education management and enhancing the cognition of its regular.

Various human nature hypotheses focus on different typical and representative features of human, which provides acquaintance and logic source for higher education management practice. As for higher education management, the subject and object of both the regulars and the regulated all point to the diversity of human beings and human nature. The legitimacy of higher education management will be out of question without doing research on human, paying attention to human and having understanding of human. Complex human beings determine the complexity of education management. The understanding of higher education management on humanity has experienced a slow developing procedure that from "instrumental man, economic man and social man" to "complex man, ecological man and educated man”. Its evolution represents the deepening and expanding understanding of human in higher education at different historical stages. It is a process rather than an event. Purpose of training ideal man requires the higher education to know, pay attention to and understand human with the present spirit, and to train, inspire and mould human.

\section{Traditional pattern and review on humanity hypothesis in higher education management}

As humanity is the foundation of higher education management, different humanity hypotheses will lead to different theories, methods and paths of higher education management. We believe that traditional management of higher education is mainly based on the following hypotheses of human nature:

\subsection{Instrumental man}

Thought of "instrumental man" is the basic view of human beings in pre Taylor era, which has become an obstruction to the development and reform of higher education management pattern. Following types of education show this management idea and its further development: military education for "cultivating tough solders" in Sparta; theological education for "cultivating clergy" in the middle ages; industrial education that set "cultivating technical talents" as the main content during the Industrial Revolution; and test-oriented education with "knowledge inculcation" as the main feature of modern education concept. The hypothesis of "instrumental man" believes that the regulated are just means of regulars to achieve their purpose, which almost disqualifies the regulated as "human beings" and ignores or denies their human factors. Its essential character is that human beings are regarded as the means and tools instead of the result and objective for management. There still exist followers after 1900s, Behaviorism represented by Waston and Skinner are the examples. They regarded human as the reactors, receivers and passive processors to stimulation in external environment, modern technology as a supreme way of learning. Human beings become machines need to be trained constantly in their eyes. They asserted for replacing school education by means of media technology. They emphasized that knowledge acquisition should depend on repeated imitation and training, and preferred stylized computer teaching. Higher education management based on this hypothesis neglects the self-consciousness and initiative, which causes the predicament in theory and practice development of higher education management.

\subsection{Economic man}

The hypothesis of "economic man” was first put forward by scholar Adam Smith, and later was introduced into the field of pedagogy as one of the most significant humanity hypotheses in sociology and management. In 1776, in the Wealth of Nation, Adam Smith argued that all individual activities are subject to "selfness". The pursuit of personal interests contributes to the common interests of the society and people who pursue their personal interest can be called "economic man". In 1960, DouglaMcGregon put forward the concept of "economic man" formally in "Theory X and Theory Y", which is a reinterpretation and re-demonstration in essence. This hypothesis can give an explanation to features, psychology and essence of decisions and choices that people make in their 
concrete real life. It began to acknowledge human requirements in economic interests and adopted material incentive to arouse the enthusiasm of the staff. Compared with the hypothesis of "instrumental man", it has positive significance. Cost reduce and efficiency improvement by means of scientific management have become a trend of times on the basis of the hypothesis of "economic man", which has profoundly influenced the formation and reform of modern higher education management. Under its influence, higher education management regarded school education management as business administration, which means it regards human as the means rather than the objective, and simplify complex education with the meaning of science, humanity, philosophy and psychology to a kind of technical work. Therefore, higher education put more emphasizes on its appearance and technology. In order to meet the requirements of social development, school management needs to enhance its talents training efficiency, which makes systematic and standard rigid higher education management become the mainstream, with the reinforced top-down bureaucracy, which leads higher education management to a institutionalize, standardized and impersonal heteronomy behavior.

\subsection{Social man}

In 1933, when scientific management advocated by Talyor an other scholars was in dilemma, Elton Mayo proposed the hypothesis of "social man" according to "Hawthorne Effect". This hypothesis argued the idea of respecting, caring and attaching importance to interpersonal relations, which made human become the center of management for the first time. "Social man" emphasizes that human beings are subject of activities that their main purpose is to pursue and meet the needs of society. What they pursue are not just money and position, but also the friendship between people, sense of security, belonging, achievement and other physiological desires. Higher education management at that time had no longer regard human beings just as a passive receiver, a economic animal, but guided their behaviors from the perspective of social needs. This kind of guidance was from the purpose of collaboration, which made a big improvement compared with scientific management pattern on the basis of "economic man". The hypothesis of "social man" noticed the importance of human psychology and their interpersonal relation, and had done a great deal of analysis and tests to work environment and descriptions, interpersonal relation and human psychology to seek for the most satisfactory condition for the workers, however, it only focused on what extent can staff satisfaction improve work efficiency, that is to say, in this view, profit is the objective of enterprise while human being is just a mean and tool of bring profits for it. This management concept is just the further development of the idea that higher education is the procedure of human socialization, which ignores the overall development of human cognition, emotion, will and behavior, and sustainability and expansibility and other abilities that people need to master after entering society.

\section{Advisable patterns of humanity hypothesis and their selection in higher education management}

Cognition of human nature in higher education management is continuously changing and evolving along with the social development. Against this major background that building first-class university and higher powerful education nation, ideas of higher education management should also keep pace with the times, in other words, we need to re-recognize and review on the humanistic basis of higher education management. We decide that following hypothesis types are advisable in higher education management, for they fully reflect the diversity, expansibility, comprehensiveness and time nature of human existence in knowledge economy and post-industrial age.

\section{1 complex man}

In 1965, EdgarH. Sehei put forward the idea of "complex man" with integrating "economic man", "social man” and "self-actualizing man”. Sehei believed that the fundamental defects of those three hypotheses lies in their over simplification and generalization.4 People's demands and 
prospective desires are varied and will constantly change along with people's age, role in society, situations and interpersonal relationships. In 1970, Super Theory proposed by John J. Morse and Jay W. Lorsh offered an conclusion about aforementioned studies of human nature, and argued that "complex man" revealed versatility of human multidimensional structure. (It reveals human nature from layers and multiaspects.) This hypothesis had been introduced into the field of education gradually as a kind of management idea, which ushered the further development of higher education management. Influenced by this idea, higher education management attached more importance to the interaction between university and environment. Higher education management had become more diverse in interest subject and more complicated in its management target with the increasing involvement of government, enterprises, and organizations in the field of higher education.

\subsection{Ecological man}

The hypothesis of "ecological man" developed from the system theory emerged at about 1940s and 1950s. It abandoned thinking model of "Instrumental man" and "economic man", and viewed relationships between man and nature from the organic systematic viewpoint: human, nature and society are conceived as an organic system. By this hypothesis, higher education management advanced a new management idea that higher education also needed to seek its own development through exchanging information and resources with the outside society for it is an open and organic social system. Means and methods of higher education management should take measures in line with conditions and circumstances, and make changes according to environmental changes. The hypothesis of "ecological man" had a more comprehensive and diverse view of human, and equipped itself with people's emotion and changing environment, which overcame one-sided and static view of previous management ideas and stresses flexible management that it should in line with conditions and circumstances. This proposal contains valuable dialectics thought and is more closer to the reality of higher education management practice, which is a significant reference for management idea of higher education to become more diversity, modern and human. Since 21st Century, China's higher education management has taken a road of connotative development and put more emphasis on Chinese characteristics, which gives powerful evidence of the hypothesis of "ecological man".

\subsection{Educated man}

Higher education management pattern based on the hypothesis of "educated man” believed that higher education management aimed to pass on culture, bring forth new ideas in learning and cultivate talents. Aristoteles had written explicitly in Metaphysics :"Human beings are born with learning." 4 The earliest hypothesis of "educated man" could be traced back to this point. Coming from abroad, it first appeared in the middle ages with its original meaning :"a person whose occupation is to think and impart his thoughts ". The concept of "educated man" had become advanced and wider with the development of times. Polish American socialist Florian Znaniecki defined it as "people who endeavor to learn", which inherited from Antiquity. It only included special groups that works for spreading and studying knowledge. Italy ideologist Antonio Gramsci divided "educated man" into traditional and organic intellectuals. The former included teacher, preachers, administrative officials, etc while the latter included people who has direct correlation and keep organic relationship with organizations, or enterprises and other social groups. And French philosopher Michel Foucault divided it into universal and special intellectuals. The former believed the basis of human existence, and behaved under the guidance of rationality, justice, truth and conscience, while the latter were experts and scholars in specific fields who queried those universal spirits compared with the universal intellectuals. Lipset made more specific division to the type of educated man, which includes creative intellectuals (scientists, research scholars, philosophers, artists,etc.), teaching intellectuals(actors, teachers, editors, doctors, lawyers, engineers, etc.) and critical intellectuals (scholars with the spirits of skeptical and critical, etc.) We can find the concept, boundary and range of "educated man" have been expanded from those definitions above: what the hypothesis stands for is no longer professional scholars or pundit, but extends to every field of 
society, that is to say, it has become the "spokesperson" of every social class.

Higher education is characterized by preserving, disseminating, developing and utilizing knowledge. " A great university should probe all fields of human knowledge and its diversity." 5 Knowledge can be regarded as the most important symbol for the leagl status of higher education. In 1968, Robert Hutchins proposed the concept of study-oriented society. It was then included by UNESCO in the contemporary important work report - Learning to be: the world of education today and tomorrow, which marked the emergence and development of study-oriented society whose key characteristic is the "educated man". In 21st century, the age of knowledge economy requires people to learn, promote and utilize the knowledge, therefore, to be an educated man with knowledge ability and accomplishment has been the mainstream of present era. Learning is no longer the privilege of people in the minority, and to be an educated man has become the mainstream values of modern society, and consequently higher education has become necessary to modern people. Higher education should never become "the battleground of class struggle" or "a factory without chimney". Today, higher education management should be based on the hypothesis of "educated man", which neither agrees with political education management mode that to arrange and design management system according to the level of authority, nor approves of instrumental education management mode that composed by interests. Higher education management model guide by the hypothesis of "educated man" not only shows the respect and publicity to human nature of higher education, but also the historical and social responsibilities of it. The concept will show its profound significance in the reform of higher education, which makes its management idea, pattern and method become more open, more diverse and more civil. Higher education management characterized by cultivating "educated man” will be a rising concern in the future.

\section{Conclusion}

Theoretically speaking, management behavior of every university will be influenced intentionally or unintentionally by humanity ideas, however, there are very few universities that manage their institutions only by means of one management mode or centralized management mode. With multi-purposes, university can be seen the coexistence of various management model in its management method and path, which is related to its social status and development strategy. It is unnecessary to argue too much on the hypothesis of higher education management, because every humanity hypothesis has its own background and scope of application. If it has more positive influences than negative one in certain time, and promote social development and progress, and provide reference and reflection on further development of higher education, there is no reason to deny its meaning and value. As a higher education manager, "there are usually theoretical model about individual and organizational behaviors on their own hypothesis to them. Both these hypotheses and their relevant theories will have impacts on their administration behavior. "6 The significance and value of research on different humanity hypotheses of higher education management under different historical periods and backgrounds is providing thinking, reference and warning managers to serve for the promotion of quality of talent cultivation in higher education.

\section{References}

[1] Zhaolong Huang. Modern educational management philosophy[M].Nanning,Guangxi Education Publishing House,1992,326.

[2] Sisk, Industrial Organization and Management[M], China Social Science Press, 1985, P201.

[3] Wenzhu An. An introduction to modern educational management[M]. Beijing Normal University Publishing House, 1995:98.

[4] Schein,Organizational Psychology[M], YuKaicheng version, Economic Management Press, 1957, P118 
[5] Leading group of Chinese and foreign University Presidents Forum of Ministry of Education. A collection of Chinese and foreign University Presidents’ Forum.Beijing[C], Higher Education Press, 2002:88.

[6] Koontz, Management[M], China Social Science Press,1987, P677. 